\title{
Synthesis and Biological Evaluation of some 3b-hydroxy-lup-20(29)-en-28-oic Acid Derivatives
}

\author{
Prince Prashant Sharma1 , Anurag' ${ }^{2}$, Ram Kumar Roy ${ }^{3}$, Rajneesh Dutt Kaushik ${ }^{4}$, Vipin Kumar Sharma ${ }^{5}$ \\ 'Department of Pharmaceutical Sciences, Faculty of Medical Sciences and Health, Gurukula Kangri University, Haridwar-249404, Uttarakhand, INDIA. \\ ${ }^{2}$ Meerut Institute of Engineering and Technology (MIET), NH-58 Meerut-Delhi Bypass, Meerut, Uttar Pradesh, INDIA. \\ Innovative College of Pharmacy, Knowledge Park-ii, Greater Noida, Uttar Pradesh, INDIA. \\ ${ }^{4}$ Department of Chemistry, Faculty of Sciences, Gurukula Kangri University, Haridwar-249404, Uttarakhand, INDIA. \\ ${ }^{5}$ Department of Pharmaceutical Sciences, Faculty of Medical Sciences and Health, Gurukula Kangri University, Haridwar-249404, Uttarakhand, INDIA.
}

\begin{abstract}
Objective: The present study projected to the synthesis of 3b-Hydroxy-lup20(29)-en-28-oic acid analogues in order to evaluate their possible biological activity. In addition, the structure-activity relationship is also investigated. Method: BA derivatives were prepared by conjugating 3b-Hydroxy-lup20(29)-en-28-oic acid with different amines through carbomyl linkage. Structures of synthesized compounds were elucidated by spectral data. Cytotoxic evaluation was done by CAM assay and MTT assay. Results: Among the synthesized compounds, Compound 7showed a pronounced cytotoxicity in antiangiogenic assay as well as compound ECV-304 cell line. Compound 10 also showed good cytotoxic activity. While compounds 6 and 8 showed moderate activity against A-549 and MCF-7 respectively. Conclusion: It is concluded that synthesized BA analogues are biologically
\end{abstract}

active and developed into useful anticancer agents.

Key words: Triterpenoids, Lupenoic acid, Carbomyl Linkage, Anticancer activity, MTT Assay.

Correspondence :

Dr. Prince Prashant Sharma,

Department of Pharmaceutical Sciences, Faculty of Medical Sciences and Health, Gurukula Kangri University, Haridwar 249404, Uttarakhand, INDIA.

Phone no: 9012014733

E-mail: princeb4me@rediffmail.com

DOI: 10.5530/jyp.2016.4.5

\section{INTRODUCTION}

3b-Hydroxy-lup-20(29)-en-28-oic acid (BA) is a derivative of Lup-20(29)ene-3 $\beta, 28$-diol which has been tested previously against various cancer cell lines. ${ }^{1,2}$ In a few recent years' researchers have added cytotoxic effect of BA against non-melanoma human cancer arrays because of two main advantage of this promising chemotherapeutic molecule which includes its selective cytotoxicity against tumour cells and its effectiveness at doses up to $500 \mathrm{mg} / \mathrm{kg}$ of body weight in treatment of HIV infection and cancer. ${ }^{3,5}$ Apoptosis irrespective of their p53 status in cancerous cells is thought to be the basic principle behind anti-cancer property of BA but only a few scientists has tested it against angiogenesis. ${ }^{6-9}$ However, among the known angiogenesis inhibitors, natural compounds such as 2-methoxyestradiol, Taxol, sulfated carbohydrates or triterpenoids have shown a tremendous potential as antiangiogenic agents. ${ }^{10-12}$

Angiogenesis or Neo-vascularization is a complicated progression or development of microvascular networks by means of red blood cell perfusion. Neo-vascularization differs from angiogenesis in that angiogenesis is mainly illustrated by the projection and consequential growth of capillary buds and nurture from previously existing blood vessels. It is one of the important physiological processes such as lesion curing along with various other diseases like cancer. Therefore, angiogenesis is marked as a potential target for evaluating newer antitumour agents. Angiogenesis is stimulated by numerous angiogenic proteinaceous factors for example fibroblast growth, Vascular endothelial growth factor (VEGF), angiopoietins (Ang1 and Ang2), matrix metalloproteinase (MMP), Delta-like ligand 4 (Dll4) etc. Some of the interesting candidates that acts as antiangiogenic agent are BEVACIZUMAB which binds with VEGF, ITRACONAZOLE inhibits VEGFR and PROLACTIN (PRL) interacts with inhibit FGF and VEGF. SEMAXANIB is an inhibitor of the Flk-1/KDR and vascular endothelial growth factor (VEGF). Till date only a small number of anti-cancer agents has good therapeutic effect against both tumour cells and are potentially efficient as angiogenesis
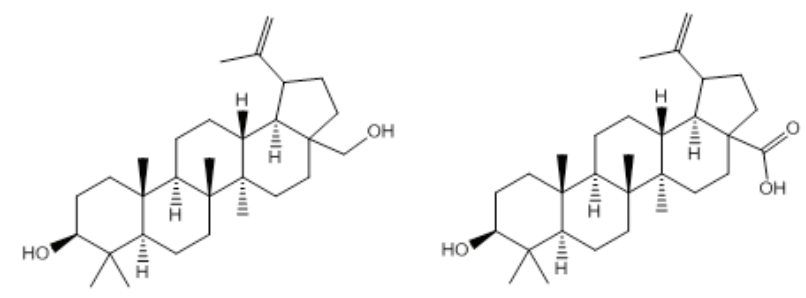

Lup-20(29)-ene-3b,28-diol (betulin; 1)

3b-Hydroxy-lup-20(29)-en-28-oic acid (Betulinic acid; 2)

inhibitors. ${ }^{13}$ Also other antimitotic agents and inhibitors of tubulin polymerization such as colchicine, vincristine inhibited angiogenesis in the CAM-assay. ${ }^{14}$ However, they also inhibited the VEGF (vascular endothelial growth factor) induced corneal vascularization in rat, in contrast to paclitaxel, which also act on tubulin. ${ }^{15}$ Here we have inspected the effectiveness of Lup-20(29)-ene-3 $\beta, 28$-diol, BA and BA derivatives against angiogenesis by utilizing structure-activity studies to develop BA analogues as antiangiogenic and anticancer agent $(2,4-6)$. In the present study the antiangiogenic activity of BA (2) and its synthetic analogues (3-9) was evaluated in the CAM (chorioallantoic membrane) assay, an in vivo model for angiogenesis as well as MTT assay. ${ }^{16}$ Even though there is an extensive choice of cytotoxic mediators used to treat different cancers, such as cisplatin, bleomycin and doxorubicin they were found to have various shortcomings in their consumption and are not as proficient as anticipated. ${ }^{17,18}$ Hence, there is a great need to find new therapeutic agents to counter the cancer. Hence, we evaluated the effects of newly synthesized compounds on MCF-7, A-549 and ECV304 cells growth.

\section{MATERIALS AND METHODS}

All synthesized compounds were characterized by their IR and ${ }^{1} \mathrm{H}-\mathrm{NMR}$ spectra. IR spectra were obtained on a Shimadzu 8400 S FT-IR spectrometer (demountable cell). ${ }^{1} \mathrm{H}-\mathrm{NMR}$ spectra were recorded on $500 \mathrm{MHz}$ 



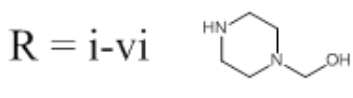

i

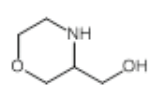

ii

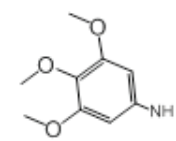

iii

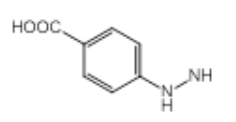

iv

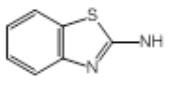

V

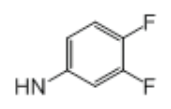

vi

Scheme 1: Schematic representation of synthetic procedure for compounds 5-10.

dpx using TMS as internal standard in DMSO, $\mathrm{CDCl}_{3}$. Melting points were determined by VEEGO melting point apparatus (Model-VMP-D/DS) and are uncorrected. Thin layer chromatography (TLC) plates (silica gel G) were used to confirm the purity of commercial reagents used, compounds synthesized and to monitor the reactions as well. Solvent systems; petroleum ether: ethyl acetate in ratio $4: 1, \mathrm{CHCl}_{3}: \mathrm{MeOH}$ (9:1) were used to run the TLC and n-Hexane: ethyl acetate in a ratio of 9:1 for chromatography purpose. The spots were located under iodine vapors/UV light. In-vivo and in-vitroctotoxicity analysis was done using CAM assay and MTT assay kit on on MCF-7, A594 and ECV304 cell lines.

\section{Synthesis of Compound 3}

The reaction mixture comprising the 3b-Hydroxy-lup-20(29)-en-28-oic acid $(0.01 \mathrm{~mol})$, boron trifluoride etherate (BTE, $0.1 \mathrm{~mol}$ depending on the number of carboxyl groups in the acid), and the appropriate amount of ethanol (ten times in excess of the boron trifluoride etherate) was taken in an RBF. Then the mixture was heated at reflux for a period of time not exceeding 20-24 h. The esters are precipitated by dilution with a $5 \%$ solution of sodium carbonate, followed by extraction with ether and purified by crystallization with appropriate solvent $\left(\mathrm{CHCl}_{3}: \mathrm{MeOH}\right)$ to afford pure compound 3 .

\section{Synthesis of Compound 4}

Equimolar quantity (10 mmol each) of 4-Nitrophenylchloroformate and 3b-Hydroxy-lup-20(29)-en-28-oic acid (2) was added slowly with a continuous stirring to the mixture of anhydrousacetonitrile $(15 \mathrm{ml})$ and triethylamine $\left(\mathrm{Et}_{3} \mathrm{~N}, 1 \mathrm{~g}\right)$ at room temperature. The mixture was then left to stir for one and half hour, during this time triethylamine hydrochloride $\left(\mathrm{Et}_{3} \mathrm{~N}\right)$ settles down. Then $20 \mathrm{ml}$ ethyl acetate (EtOAc) was added to the mixture previously rinsed three times. The organic layer was dried over anhydrous magnesium sulphate $\left(\mathrm{MgSO}_{4}\right)$. The mixture was filtered to remove magnesium sulphate $\left(\mathrm{MgSO}_{4}\right)$. Solid product residue was obtained as compound 4 .

\section{Synthesis of Compound 5-10}

2-(piperazin-1-yl) ethanol $(0.0196 \mathrm{~mL})$ and the appropriate amine were taken and was stirred at 0 to $-5^{\circ} \mathrm{C}$ for $20 \mathrm{~min}$. The mixture was then subjected to Sodium hydroxide $(1.0 \mathrm{mmol})$ and methanol $40 \mathrm{ml}$ were added to a stirred solution in THF $(20 \mathrm{ml})$. The solution was stirred approximately $6 \mathrm{hr}$ at ambient temperature until compound 5 had been converted to baseline product. Solvents were removed under reduced pressure $\left(\leq 20^{\circ} \mathrm{C}\right)$ and the crude material was subjected to dichloromethane /water $\left(\mathrm{CH}_{2} \mathrm{Cl}_{2} / \mathrm{H}_{2} \mathrm{O}\right)$ extraction. Ice was added and the $\mathrm{pH}$ was carefully adjusted to $\approx 3$ by drop-wise addition of $1 \% \mathrm{HCl}(\mathrm{aq})$. Washing of aqueous layer was done with dichloromethane until the organic layer becomes transparent to UV. The combined organic layers were dried by anhydrous sodium sulphate $\left(\mathrm{Na}_{2} \mathrm{SO}_{4}\right)$, and then filtered. Volatiles were evaporated under reduced pressure $\left(\leq 20^{\circ} \mathrm{C}\right)$ to give $5(120 \mathrm{mg})$. The synthesis of compounds 6-10 was performed according to the same procedure as for 5 using appropriate amines.

\section{Biological Evaluations Chorioallantoic Membrane (CAM) Assay}

CAM assay is routinely used as a preliminary method to determine antiangiogenic effect of a compound. This assay is based upon the formation of a chorioallantoic membrane, in which neovascularization takes place, in fertilized chicken eggs at a certain stage of the development of the embryo. Agarose pellets impregnated with the test compound are placed onto the vascular membrane of opened eggs, and the influence on angiogenesis is evaluated. For assay purpose the fertile chicken eggs were procured from Local hatchery, JWALAPUR, HARIDWAR. Twelve eggs were used per experiment to test one compound as a given dose. The eggs were fertilized at $37^{\circ} \mathrm{C}$ and $80 \%$ relative humidity in ideal conditions. The shells of eggs were cleaned with $70 \% \mathrm{EtOH}$ to avoid infections. After $72 \mathrm{hrs} 8-10 \mathrm{ml}$ of albumin was removed with a syringe at the lower side of the egg, and the hole was sealed with tape. Subsequently the upper part of the shell was removed, and the eggs were covered with a plastic film and incubated for another $72 \mathrm{hrs}$. At this point of time, when the diameter of CAM is between 1.8 and $2.6 \mathrm{~cm}$, the pellets containing the test substances were placed on the CAM. Test substances were first dissolved or suspended in smallest quantity of DMF and afterwards mixed with $2.5 \%$ agarose solution. After gel formation, the volume of agarose gel corresponding to the dose of the test compound to be applied to the CAM was taken by means of a micropipette for viscous solutions. Therefore, the agarose pellets do not have a uniform size. The half-coneshaped agarose pellets are fixed because they slightly sink into the CAM. After $24 \mathrm{hrs}$ the antiangiogenic effect was measured after addition of cream as a contrast fluid, by means of a stereomicroscope, by observing the avascular zone surrounding the pellet. Antiangiogenic activity is expressed as a score where $0=$ no or weak effect, $1=$ medium effect, and $2=$ strong effect (capillary free zone is at least twice as large as the pellet). Also membrane irritation and embryotoxicity can be evaluated. B-1,4galactan sulfate (LuPS S5) with an average molecular weight of 20000 was used as positive control 46 and an agarose pellet as a blank.

\section{Cell Proliferation Assays}

Add $10 \mu \mathrm{L}$ of the $12 \mu \mathrm{M}$ MTT stock solution to each well. Include a negative control of $10 \mu \mathrm{L}$ of the MTT stock solution added to $100 \mu \mathrm{L}$ of medium alone. Incubate at $37^{\circ} \mathrm{C}$ for $4 \mathrm{hrs}$. The incubation time can be shortened to $2 \mathrm{hrs}$ at high densities (more than 100,000) cells per well. 
Table 1: Antiangiogenic and anticancer activity of investigated compounds on tumour cell lines by MTT assay

\begin{tabular}{|c|c|c|c|c|}
\hline \multirow[b]{2}{*}{$\begin{array}{c}\text { Test } \\
\text { compound }\end{array}$} & Antiangiogenic & MCF-7 & A-549 & ECV304 \\
\hline & $\begin{array}{l}\text { ( } n=\text { no. of } \\
\text { experiment) }\end{array}$ & \multicolumn{3}{|c|}{$I C_{50}(\mu M)$} \\
\hline 2 & $1.8+0.1(\mathrm{n}=3)$ & [a] & {$[\mathrm{b}]$} & {$[c]$} \\
\hline 5 & $0.8 \pm 0.1(n=3)$ & 49.55 & 35.18 & 47.22 \\
\hline 6 & $1.4 \pm 0.1(\mathrm{n}=3)$ & 44.66 & 31.41 & 44.81 \\
\hline 7 & $1.5+0.1(\mathrm{n}=3)$ & 36.71 & 41.63 & 08.35 \\
\hline 8 & $1.4 \pm 0.1(\mathrm{n}=3)$ & 32.36 & 61.85 & 45.53 \\
\hline 9 & $1.0 \pm 0.1(\mathrm{n}=3)$ & 34.82 & 57.88 & 47.22 \\
\hline 10 & $0.8 \pm 0.1(\mathrm{n}=3)$ & 45.5 & 32.29 & 10.90 \\
\hline $\begin{array}{l}\text { Agarose } \\
\text { pellet }\end{array}$ & $0.1 \pm 0.1(\mathrm{n}=10)$ & -- & -- & -- \\
\hline $\begin{array}{c}\mathrm{b} 14 \mathrm{~g} 50 \\
(2.5 \mathrm{nmol})\end{array}$ & $1.4 \pm 0.1(\mathrm{n}=10)$ & -- & -- & -- \\
\hline
\end{tabular}

$\mathrm{IC}_{50}:$ Inhibitory concentration $(\mu \mathrm{M})$ of test compounds; n.t: not tested; SD: Standard deviation.

b14g50: $\beta$-1,4-galactan sulphate (LuPS S5)

$[\mathrm{a}],[\mathrm{b}],[\mathrm{c}]=2,{ }^{19} 3,{ }^{20} 1.26^{21}$

a) BTE, b) 4-nitrophenyl chloroformate, TEA, $\mathrm{CH}_{2} \mathrm{Cl}_{2}$, toluene, c) 2-(piperazin-1-yl) ethanol or appropriate amine ( $\mathrm{R}=\mathrm{i}$-vi), $\left.\mathrm{CHCl}_{3}, \mathrm{~d}\right) \mathrm{NaOH}, \mathrm{H}_{2} \mathrm{O}$, $\mathrm{MeOH}, \mathrm{THF}$

Add $100 \mu \mathrm{L}$ of the SDS-HCl solution to each well and mix thoroughly using the pipette. Micro plates were placed for incubation at $37^{\circ} \mathrm{C}$ for $4 \mathrm{hrs}$ in a moistened chamber. The sensitivity of the assay will get decrease over long incubation period. Mixing of each sample was repeated using a pipette and absorbance was observed at $570 \mathrm{~nm}$.

\section{RESULTS}

\section{Chemistry}

Based on the reaction between compounds containing hydroxyl groups, 3b-Hydroxy-lup-20(29)-en-28-oic acid (2), 4-nitrophenyl chlorformate and appropriate amines (i-v) we have synthesized some novel derivatives of 3b-Hydroxy-lup-20(29)-en-28-oic acid (5-10). For this purpose, the hydroxyl group of 2 was subjected to 4-nitrophenyl chlorformate to give compound 4 . The compound 4 was further exposed to various amines to obtain compounds 5-10. Ethyl carboxylate derivative of 3b-Hydroxylup-20(29)-en-28-oic acid (2) has been synthesized from 3b-Hydroxylup-20(29)-en-28-oic acid. The 3-OH group of compound 3 is substituted with 4-nitrophenyl chlorformate in the presence of TEA and $\mathrm{CH}_{2} \mathrm{Cl}_{2}$ to yield compound 4 . The nitro phenoxy group at the $\mathrm{C}-3$ position is replaced with various appropriate amine $(\mathrm{R})$ in the presence of $\mathrm{CHCl}_{3}$, giving 5-10 (Scheme 1). All compounds were obtained as in a good yield. All the compounds were chromatographed with ethyl acetate-n Haxane (1:9) to obtain pure compounds. The synthetic organic methods followed in preparing the compounds in series 3-10 are sketched in Scheme 1.

\section{Physical and spectral data of synthesized compounds} 3b-hydroxy-28-norlup-20(29)-en-17-carboxylate (3)

Yield of $81 \% \mathrm{mp} .171-175^{\circ} \mathrm{C}$; FT-IR $\left(v_{\max } \mathrm{cm}^{-1}\right): 3450,2980,1710,1298$, 1665, 1628 and 884; ${ }^{1} \mathrm{H}-\mathrm{NMR}$ spectrum (500 MHz, DMSO, $\delta, \mathrm{ppm}$ ) $0.790\left(3 \mathrm{H}, \mathrm{s}, 24-\mathrm{CH}_{3}\right), 0.835\left(3 \mathrm{H}, \mathrm{s}, 23-\mathrm{CH}_{3}\right), 0.912\left(3 \mathrm{H}, \mathrm{s}, 27-\mathrm{CH}_{3}\right)$, $0.986\left(3 \mathrm{H}, \mathrm{s}, 25-\mathrm{CH}_{3}\right), 0.989\left(3 \mathrm{H}, \mathrm{s}, 26-\mathrm{CH}_{3}\right), 1.275-1.112$ (complex, $\left.\mathrm{CH}_{2}, \mathrm{CH}\right), 1.687\left(3 \mathrm{H}, \mathrm{s}, 30-\mathrm{CH}_{3}\right), 2.199(1 \mathrm{H}, \mathrm{m}, 19-\mathrm{H}), 3.800(1 \mathrm{H}$,

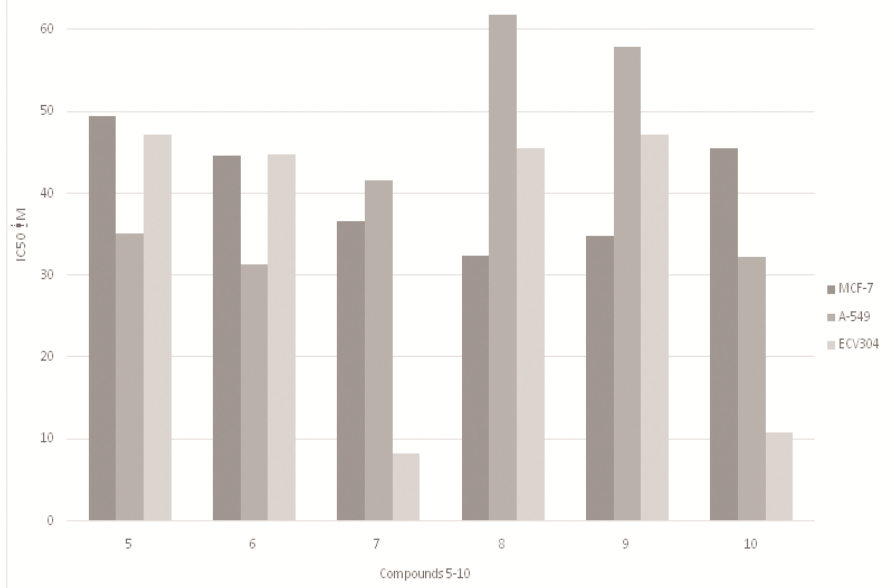

Figure 1: Anticancer Effect of Compounds on Different Cell lines.

3-H), $3.881\left(2 \mathrm{H}, \mathrm{CH}_{3}\right), 1.310\left(3 \mathrm{H}, \mathrm{CH}_{3}\right), 4.695(\mathrm{H}, \mathrm{s}, 29-\mathrm{H}), 4.793(\mathrm{H}$, s, 29-H).

3-((4-nitrophenoxy)carbonyl)oxy-lup-20(29)-en-28oic-acid (4)

Mp. 215-230 ${ }^{\circ}$; FT-IR (KBr, $\mathrm{v}_{\max } \mathrm{cm}^{-1}$ ) 1105, 1163, 1222, 1310 (C-O), 1371, 1399, 1441, 1489, 1609, 1597 (C=C, cis/vinyl strong; trans weak), 1701 (narrow, $\mathrm{C}=\mathrm{O}$ ), 3000 (broad, $\mathrm{C}-\mathrm{H}) ;{ }^{1} \mathrm{H}-\mathrm{NMR}$ (500 MHz, DMSO): $0.881\left(3 \mathrm{H}, \mathrm{s}, \mathrm{CH}_{3}-24\right), 0.915\left(3 \mathrm{H}, \mathrm{CH}_{3}-25\right), 0.928\left(3 \mathrm{H}, \mathrm{CH}_{3}-27\right), 0.958$ (3H, $\left.\mathrm{CH}_{3}-23\right), 0.972\left(3 \mathrm{H}, \mathrm{CH}_{3}-26\right), 1.573-1.252$ (complex, $\mathrm{CH}_{2}, \mathrm{CH}$ ), $1.875\left(3 \mathrm{H}, \mathrm{CH}_{3}-30\right), 3.842$ (1H, H-19), $3.768(1 \mathrm{H}, \mathrm{H}-3), 5.074\left(1 \mathrm{H}, \mathrm{H}_{\mathrm{b}}-29\right)$, 5.173 (1 H, br. s, Ha-29), 7.205-7.414 (2H, Ar-H), 7.623-7.899 (2H, Ar-H).

\section{3-(4-(hydroxymethyl)piperazine-1-carbonyl)oxy-lup- 20(29)-en-28-oic acid (5)}

Mp. 270-288 ${ }^{\circ}$; FT-IR (KBr, $\left.\mathrm{v}_{\max } \mathrm{cm}^{-1}\right) 3471,3070,1734,1642,1244$, 1102,$880 ;{ }^{1} \mathrm{H}-\mathrm{NMR}$ spectrum (500 MHz, DMSO, $\left.\delta, \mathrm{ppm}\right): 0.960(3 \mathrm{H}, \mathrm{s}$, $\left.24-\mathrm{CH}_{3}\right), 0.974\left(3 \mathrm{H}, \mathrm{s}, 23-\mathrm{CH}_{3}\right), 1.103,1.129,1.250(9 \mathrm{H}, \mathrm{s}, 25,26$, $\left.27-\mathrm{CH}_{3}\right), 1.374\left(7 \mathrm{H}, \mathrm{CH}_{2}\right), 1.630\left(3 \mathrm{H}, \mathrm{s}, 30-\mathrm{CH}_{3}\right), 2.200(1 \mathrm{H}, 19-\mathrm{C}), 2.279$ $\left(2 \mathrm{H}, \mathrm{CH}_{2}\right.$, piperazinyl), $2.536\left(2 \mathrm{H}, \mathrm{CH}_{2}\right.$, piperazinyl $), 2.825\left(2 \mathrm{H}, \mathrm{CH}_{2}\right.$, piperazinyl), $3.031\left(2 \mathrm{H}, \mathrm{CH}_{2}\right.$, piperazinyl $), 3.512\left(1 \mathrm{H}, \mathrm{C}_{2} \mathrm{H}_{4}\right), 3.65(1 \mathrm{H}, \mathrm{d}$, $\left.\mathrm{C}_{2} \mathrm{H}_{4}\right), 3.803(1 \mathrm{H}, 3-\mathrm{C}), 4.995\left(1 \mathrm{H}, 29-\mathrm{H}_{\mathrm{b}}\right), 5.129\left(1 \mathrm{H}, 29-\mathrm{H}_{\mathrm{a}}\right)$.

\section{3-(3-(hydroxymethyl)morpholine-4-carbonyl)oxy-lup- 20(29)-en-28-oic acid (6)}

Mp. 287-298 ${ }^{\circ}$; FT-IR (KBr, $\left.v_{\text {max }} \mathrm{cm}^{-1}\right)$ 3440, 3070, 1729, 1642,1246, 978, 882; ${ }^{1} \mathrm{H}-\mathrm{NMR}$ spectrum (500 MHz, DMSO, $\left.\delta, \mathrm{ppm}\right): 0.916(3 \mathrm{H}, \mathrm{s}$, $\left.24-\mathrm{CH}_{3}\right), 0.914\left(3 \mathrm{H}, \mathrm{s}, 23-\mathrm{CH}_{3}\right), 1.113,1.139,1.260\left(9 \mathrm{H}, \mathrm{s}, 25,26,27-\mathrm{CH}_{3}\right)$, $1.371\left(7 \mathrm{H}, \mathrm{CH}_{2}\right), 1.631\left(3 \mathrm{H}, \mathrm{s}, 30-\mathrm{CH}_{3}\right), 2.201(1 \mathrm{H}, 19-\mathrm{C}), 3.183(1 \mathrm{H}$, 3-C), $3.505\left(1 \mathrm{H}, \mathrm{CH}_{3}\right), 3.581\left(2 \mathrm{H}, \mathrm{CH}_{2}\right.$, morpholine $), 3.595(1 \mathrm{H}, \mathrm{CH}$, morpholine), $3.822\left(2 \mathrm{H}, \mathrm{CH}_{2}\right.$, morpholine), $3.851\left(2 \mathrm{H}, \mathrm{CH}_{2}\right.$, morpholine), $4.969\left(1 \mathrm{H}, 29-\mathrm{H}_{\mathrm{b}}\right), 5.122\left(1 \mathrm{H}, 29-\mathrm{H}_{\mathrm{a}}\right)$.

\section{3-(3,4,5-trimethoxyphenyl)carbamoyl-oxy-lup-20(29)- en-28-oic acid (7)}

Mp. 279-284 ${ }^{\circ} \mathrm{C}$; FT-IR (KBr, $\left.\mathrm{v}_{\max } \mathrm{cm}^{-1}\right)$ 3320,3070, 1720, 1643; ${ }^{1} \mathrm{H}-\mathrm{NMR}$ spectrum (500 MHz, DMSO, $\delta$,ppm): $0.910\left(3 \mathrm{H}, \mathrm{s}, 24-\mathrm{CH}_{3}\right), 0.904(3 \mathrm{H}, \mathrm{s}$, $\left.23-\mathrm{CH}_{3}\right), 1.114,1.119,1.214\left(3 \mathrm{x} 3 \mathrm{H}, \mathrm{s}, 25,26,27-\mathrm{CH}_{3}\right), 1.364\left(7 \mathrm{H}, \mathrm{CH}_{2}\right)$, $1.710\left(3 \mathrm{H}, \mathrm{s}, 30-\mathrm{CH}_{3}\right), 2.400(1 \mathrm{H}, 19-\mathrm{C}), .331(1 \mathrm{H}, 3-\mathrm{C}), 3.583(3 \times 3 \mathrm{H}$, 
$\mathrm{CH}_{3}$, trimethoxy), $4.889\left(1 \mathrm{H}, 29-\mathrm{H}_{\mathrm{b}}\right), 5.112\left(1 \mathrm{H}, 29-\mathrm{H}_{\mathrm{a}}\right), 6.662-6.820$

$(2 \mathrm{H}-\mathrm{Ar}-\mathrm{H}), 8.801(1 \mathrm{H}, \mathrm{NH})$.

\section{3-(2-(4-carboxyphenyl)hydrazinecarbonyl)oxy-lup- 20(29)-en-28-oic acid (8)}

Mp. $271-281^{\circ} \mathrm{C}$; FT-IR (KBr, $\mathrm{v}_{\max } \mathrm{cm}^{-1}$ ) 3073, 1735, 1642, 1241, 880; ${ }^{1} \mathrm{H}-\mathrm{NMR}$ spectrum $\left(500 \mathrm{MHz}, \mathrm{DMSO}, \delta\right.$,ppm): $0.916\left(3 \mathrm{H}, \mathrm{s}, 24-\mathrm{CH}_{3}\right)$, $0.917\left(3 \mathrm{H}, \mathrm{s}, 23-\mathrm{CH}_{3}\right), 1.131,1.291,1.295\left(9 \mathrm{H}, \mathrm{s}, 25,26,27-\mathrm{CH}_{3}\right), 1.314$ $\left(7 \mathrm{H}, \mathrm{CH}_{2}\right), 1.660\left(3 \mathrm{H}, \mathrm{s}, 30-\mathrm{CH}_{3}\right), 2.260(1 \mathrm{H}, 19-\mathrm{C}), 3.803(1 \mathrm{H}, 3-\mathrm{C})$, $4.995\left(1 \mathrm{H}, 29-\mathrm{H}_{\mathrm{b}}\right), 5.129\left(1 \mathrm{H}, 29-\mathrm{H}_{\mathrm{a}}\right), 6.101-7.800(4 \mathrm{H}-\mathrm{Ar}), 8.010(1 \mathrm{H}$, $\mathrm{NH})$.

\section{3-((benzothiazol-2-ylcarbamoyl)oxy)-lup-20(29)-en-28-} oic acid (9)

Mp. 279-291 ${ }^{\circ} \mathrm{C}$; FT-IR (KBr, $\left.\mathrm{m}_{\max } \mathrm{cm}^{-1}\right)$ 3073, 1735, 1642, 2140, 1241, 880; ${ }^{1} \mathrm{H}-\mathrm{NMR}$ spectrum $(500 \mathrm{MHz}, \mathrm{DMSO}, \boldsymbol{\delta}, \mathrm{ppm}): 0.946\left(3 \mathrm{H}, \mathrm{s}, 24-\mathrm{CH}_{3}\right)$, $0.947\left(3 \mathrm{H}, \mathrm{s}, 23-\mathrm{CH}_{3}\right), 1.109,1.111,1.115\left(9 \mathrm{H}, \mathrm{s}, 25,26,27-\mathrm{CH}_{3}\right), 1.422$ $\left(7 \mathrm{H}, \mathrm{CH}_{2}\right), 1.760\left(3 \mathrm{H}, \mathrm{s}, 30-\mathrm{CH}_{3}\right), 2.211(1 \mathrm{H}, 19-\mathrm{C}), 3.603(1 \mathrm{H}, 3-\mathrm{C})$, $4.695\left(1 \mathrm{H}, 29-\mathrm{H}_{\mathrm{b}}\right), 5.009\left(1 \mathrm{H}, 29-\mathrm{H}_{\mathrm{a}}\right), 6.118-7.180(4 \mathrm{H}-\mathrm{Ar}), 8.110(1 \mathrm{H}$, $\mathrm{NH})$.

\section{(3,4-difluorophenyl)carbamoyl-oxy)-20(29)-lupene-28- oic acid (10)}

Mp. 207-211 ${ }^{\circ} \mathrm{C}$; FT-IR (KBr, $\left.\mathrm{v}_{\max } \mathrm{cm}^{-1}\right)$ 3070, 1725, 1632, 2137, 1240, 788; ${ }^{1} \mathrm{H}-\mathrm{NMR}$ spectrum (500 MHz, DMSO, $\delta$,ppm): $0.944\left(3 \mathrm{H}, \mathrm{s}, 24-\mathrm{CH}_{3}\right.$ ), $0.946\left(3 \mathrm{H}, \mathrm{s}, 23-\mathrm{CH}_{3}\right), 1.106,1.109,1.110,\left(9 \mathrm{H}, \mathrm{s}, 25,26,27-\mathrm{CH}_{3}\right), 1.419$ $\left(7 \mathrm{H}, \mathrm{CH}_{2}\right), 1.755\left(3 \mathrm{H}, \mathrm{s}, 30-\mathrm{CH}_{3}\right), 2.201(1 \mathrm{H}, 19-\mathrm{C}), 3.613(1 \mathrm{H}, 3-\mathrm{C})$, $4.675\left(1 \mathrm{H}, 29-\mathrm{H}_{\mathrm{b}}\right), 5.09\left(1 \mathrm{H}, 29-\mathrm{H}_{\mathrm{a}}\right), 9.10(1 \mathrm{H}-\mathrm{NH}), 7.35-7.77(3 \mathrm{H}, \mathrm{Ar})$.

\section{Biological Activity}

All the compounds were evaluated for their antiangiogenic activity. b14g50 was used as standard drug for antiangiogenic activity. The observed antiangiogenic ac activity of the compounds and reference rug $\mathrm{s}$ are given in Table 1 . Compound 3 , the acetate derivative of $3 \mathrm{~b}$ Hydroxy-lup-20(29)-en-28-oic acid methyl ester, showed an antiangiogenic score of more than 1.5 and compound 2 was evaluated at $20 \mu \mathrm{g} /$ pellet and revealed good antiangiogenic property with a score 1.8. Substitution on the parent compound reduced the antiangiogenic activity. Indeed, in the same series of 3b-Hydroxy-lup-20(29)-en-28-oic acid demonstrated the most potent inhibition of angiogenesis. Since the proliferation of endothelial cells is involved in angiogenesis, the antiangiogenic effect of the agents may be related to their anti-proliferative action on endothelial cells. Compound 2 can be regard as a lead for antiangiogenic agents, which deserve further exploration. The observedantiangiogenic effects of the compounds are summarized in Table 1. All the compounds [5-10] were evaluated for in-vitro cytotoxic activity of the 3b-Hydroxy-lup-20(29)-en-28-oic acid derivatives on three different tumour cell lines: ECV304, A594, MCF-7 was studied by MTT assay in triplicate. The compounds showed anticancer activity in a dose dependent manner against selected cell lines. The observed inhibitory concentration values of $50 \%$ inhibition are summarized in Table 1. From the results of antiangiogenic and cytotoxic screening, it was observed that among the various compounds, 3,4-difloro-aniline derivative 10 exhibited leading activity over the series. Results of anticancer screening are shown in Table 1 and graphical representation of comparative study for comparative study for effect of compounds on MCF-7, A594 and ECV304 cell lines by MTT assay are shown in Figure 1. All the screened compounds showed apparent anticancer activity, against selected cell line, with $\mathrm{IC}_{50}$ in range from 08.35 to $61.85 \mu \mathrm{M}$ on different tumour cell lines except compounds $8\left(\mathrm{IC}_{50}=61.85 \mu \mathrm{M}\right)$ on A-549 cancer cell line. In the study Compound 7 and 10 were found most active compound among synthesized derivatives against tumour cell lines used. The best activity of 3,4,5-trimethoxyBA derivative (7) and 3,4-difluorophenyl-BA derivative(10)was observed on ECV-304 cell line $\left(\mathrm{IC}_{50}=08.35\right.$ and 10.90 $\mu \mathrm{M}$ respectively). Remarkably, the 3b-Hydroxy-lup-20(29)-en-28-oic acid derivatives 07 was also found most active against in CAM assay. In overall performance Compounds 6 and 8 showed good activity on A-549 and MCF-7 cell lines. While in most of the cases the heterocyclic BA derivatives 5, 6, and 9 show mild activity as compared to 3b-Hydroxylup-20(29)-en-28-oic acid derivative 7 and 10 on the investigated tumour cell lines. A variation of secondary $-\mathrm{OH}$ group at $3^{\text {rd }}$ position with heterocyclic urethanes may be designated as the cause for reduced activity in compound 5-10. Alternatively, replacement of hydroxyl group with phenyl urethane yields most cytotoxic derivatives. The owing the rigidity of aromatic group may lead to the loss of activity in phenyl urethanes derivatives and on the other end it can be assumed that introduction of a bulkier groups onto lead to inactive molecules.

\section{CONCLUSION}

In conclusion, we have demonstrated the preparation of novel derivatives of 3b-Hydroxy-lup-20(29)-en-28-oic acid and the derivatives were evaluated for antiangiogenic and in vitro anticancer activity on three cancer cell lines. Compounds 7 and 10 were established utmost cytotoxic between the derivatives synthesized. Furthermore, compounds 7 exhibit a good mark of in-vitro stability. Thus the results show that synthesized compounds possess antiangiogenic and anticancer activities. The synthesized compounds were obtained in suitable yields Structure activity relationship shows that the cytotoxicity was decreased after introducing bulkier groups at 3-hydroxy group of 3b-Hydroxy-lup-20(29)-en-28-oic acid (2). This study reveals that modest alterations in the $3 \mathrm{~b}-$ Hydroxylup-20(29)-en-28-oic acid can be done to yield numerous extremely potent derivatives, which may lead to generation of more effective treatment of cancer. Although, there is great need of large number of derivatives for structure activity relationship (SAR) in the way to design and synthesis novel effective 3b-Hydroxy-lup-20(29)-en-28-oic acid analogues as antitumor agents. However, additional studies are required to establish the mechanism of action.

\section{ACKNOWLEDGEMENT}

None.

\section{CONFLICT OF INTEREST}

All authors have none to declare. 


\section{ABBREVIATIONS USED}

BA: 3b-Hydroxy-lup-20(29)-en-28-oic acid; CAM: Chorioallantoic Membrane; VEGF: Vascular Endothelial Growth Factor; MTT: 3-(4, 5-dimethylthiazolyl-2)-2, 5-diphenyltetrazolium bromide; TMS: Tetra Methyl Silane; DMSO: Dimethyl Sulfoxide; $\mathbf{C D C l}_{3}$ : Deuterated Chloroform; $\mathbf{B T E : ~ B o r o n ~ T r i f l u o r i d e ~ E t h e r a t e ; ~ D M F : ~}$ Dimethylformamide.

\section{ABOUT AUTHORS}

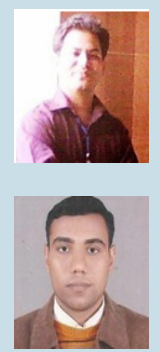

Prince Prashant Sharma M.Pharm., Ph. D (Pharmaceutical Science): Is Assistant Professor and a researcher at the at the Gurukul Kangri University, Haridwar. His research areas include Analytical and Medicinal Chemistry, Cancer Research, Epilepsy Research and Natural Products

Anurag M. Pharm., Ph. D (Pharmaceutical Science): Is Assistant Professor and a researcher at the at the Meerut Institute of Engineering and Technology, Meerut, Uttar Pradesh. His research areas include Spectroscopy, Medicinal Chemistry, and Cancer Research.

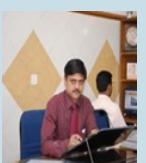

Prof. Ram Kumar Roy M. Pharm., Ph. D (Pharmaceutical Science): He has 20 years of academic and research experience at UG and PG level. His area of interest includes Phyto-Chemical Screening, Herbal formulations and standardization, Ethno Pharmacological Evaluation, Semi-synthetic \& Synthetic Compounds Synthesis, Biosynthetic Studies.

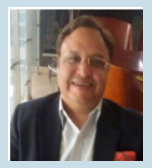

Rajneesh Dutt Kaushik, M.Sc., Ph.D.: He is Professor of Chemistry, at Department of Chemistry, Gurukul Kangri University, Haridwar. His research areas include Physico-organic (Reaction Kinetics and Mechanism) and Physico-analytical chemistry, Plant Chemistry. For more info [http://gkv.ac.in/?page_id=2885]

Vipin Kumar Sharma M.Pharm., Ph. D (Pharmaceutical Science): Is a Assistant Professor and a researcher at the at the Gurukul Kangri University, Haridwar. His research areas include Screening of new chemical entities as pharmaceuticals, Novel Drug Delivery Systems, Bioavailability enhancement, Drug Pharmacokinetics, Drug Targeting, Biopolymers and biomedical polymers composites, Natural Products.

\section{REFERENCES}

1. Zuco V, Supino R, Righetti S, Cleris L, Marchesi E, Gambacorti-Passerini C et al. Selective cytotoxicity of betulinic acid on tumor cell lines, but not on normal cells. Cancer Lett. 2002;175(1):17-25

2. Damle A, Pawar Y, Narkar A. Anticancer activity of betulinic acid on MCF-7 tumors in nude mice. Indian J Exp Biol. 2013;51(7):485-91.

3. Cichewicz R, Kouzi S. Chemistry, Biological Activity and Chemotherapeutic Potential of Betulinic Acid for the Prevention and Treatment of Cancer and HIV Infection. Med Res Rev. 2004;24(1):90-114.

4. Kim D, Pezzuto J, Pisha E. Synthesis of betulinic acid derivatives with activity against human melanoma. Bioorganic \& Medicinal Chemistry Letters. 1998; 8(13):1707-12

5. Mullauer F, Kessler J, Medema J. Betulinic acid, a natural compound with potent anticancer effects. Anti-Cancer Drugs. 2010;21(3):215-27.

6. Sawada N, Kataoka K, Kondo K, Arimochi H, Fujino H, TakahashiY et al. Betulinic acid augments the inhibitory effects of vincristine on growth and lung metastasis of B16F10 melanoma cells in mice. Br J Cancer. 2004;90(8):1672-8.

7. Bache M, Zschornak M, Passin S, KeÃ̈̈ler J, Wichmann H, Kappler M et al. Increased betulinic acid induced cytotoxicity and radiosensitivity in glioma cells under hypoxic conditions. Radiat Oncol. 2011;6(1):111.

8. Fulda S, Friesen C, Los M, Scaffidi C, MierW, Benedict M, Nunez et al. Betulinic Acid Triggers CD95 (APO-1/Fas)- and p53-independent Apoptosis via Activation of Caspases in Neuroectodermal Tumors. Cancer Res. 1997;57(21):4956-64.

9. Selzer E, Pimentel E, Wacheck V, Schlegel W, Pehamberger H, Jansen B, et al. Effects of Betulinic Acid Alone and in Combination with Irradiation in Human Melanoma Cells. J Invest Dermatol. 2000;114(5):935-40.

10. Mukherjee $R$, Jaggi M, Rajendran P, Siddiqui M, Srivastava S, Vardhan A, et al. Betulinic acid and its derivatives as anti-angiogenic agents. Bioorganic \& Med Chem Lett. 2004;14(9):2181-4

11. Paper D. Natural Products as Angiogenesis Inhibitors. Planta Med. 1998; 64(08):686-95
12. Klauber N, Parangi S, Flynn E, Hamel E, D'Amato R. Inhibition of angiogenesis and breast cancer in mice by the microtubule inhibitors 2-methoxyestradiol and taxol. Cancer Res. 1997;57(1):81-6.

13. Lee S. Anticancer effects of KI-10F: A novel compound affecting apoptosis angiogenesis and cell growth in colon cancer. Int J Oncol. 2012;41(5):1715-22.

14. Mahboobi S, Pongratz H, Hufsky H, Hockemeyer J, Frieser M, Lyssenko A, et al. Synthetic 2-Aroylindole Derivatives as a New Class of Potent Tubulin-Inhibitory, Antimitotic Agents. J Med Chem. 2001;44(26):4535-53.

15. Hotchkiss, K, Ashton A, Mahmood R, Russell R, Sparano J, Schwartz E. Inhibition of Endothelial Cell Function in vitro and Angiogenesis in vivo by Docetaxe (Taxotere): Association with Impaired Repositioning of the Microtubule Organizing Center 1 Supported by grants from the National Cancer Institute (Grants R01-CA54422, RO1-CA89352, and P01-CA13330), Aventis Pharmaceuticals, and UJA-Federation of New York. Mol Cancer Ther. 2002;1(13):1191-200.

16. Anurag, Roy RK, Sharma PP. Synthesis and antiangiogenic activity of some nov el analogues of Combretastatin A-4. Int J of Pharm Tech Res. 2009;1 (4):1462-9.

17. Kim D, Hong G, Lee H, Choi S, Chun B, Won C, et al. Effect of colloidal silver against the cytotoxicity of hydrogen peroxide and naphthazarin on primary cultured cortical astrocytes. Int J Neurosci. 2007;117(3):387-400.

18. Beg T, Siddique $Y$, Afzal M. Protective Action of Flavonoids Genistein Gingerol against Cisplatin Toxicity In vitro. Journal of Young Pharmacists. 2012:4(2):124-5.

19. Mukherjee R, Jaggi M, Rajendran P, Siddiqui M, Srivastava S, Vardhan A, et al Betulinic acid and its derivatives as anti-angiogenic agents. Bioorganic \& Med Chem Lett. 2004;14(9):2181-4.

20. Hussein-Al-Ali S, Arulselvan P, Fakurazi S, Hussein M. The in vitro therapeutic activity of betulinic acid nanocomposite on breast cancer cells (MCF-7) and normal fibroblast cell (3T3). J Mater Sci. 2014;49(23):8171-82.

21. Kumar $V$, Rani $N$, Aggarwal $P$, Sanna $V$, Singh $A$, Jaggi $M$ et al. Synthesis and cytotoxic activity of heterocyclic ring-substituted betulinic acid derivatives. Bioorganic \& Med Chem Lett. 2008;18(18):5058-62. 